\title{
Pediatric Disorders with Autonomic Dysfunction: What Role for PHOX2B?
}

\author{
CLAUDE GAULTIER, HA TRANG, STÉPHANE DAUGER, AND JORGE GALLEGO \\ INSERM U676 [C.G., S.D., J.G.], Services de Physiologie [C.G., H.T.] et de Réanimation Médicale \\ Pédiatrique [S.D.], Hôpital Robert Debré, 75019 Paris, France
}

\begin{abstract}
Hirschsprung disease, neuroblastomas, and congenital central hypoventilation syndrome can occur in combination, and familial cases have been reported in all three conditions. This suggests variable expression of a single genetic abnormality as the common cause to these neural crest disorders. Because the PHOX $2 \mathrm{~B}$ gene is pivotal in the development of most relays of the autonomic nervous system, including all autonomic neural crest derivatives, it was considered a candidate gene for the above conditions. Recent studies have shown that 1) $P H O X 2 B$ is the main disease-causing gene for congenital central hypoventilation syndrome, an autosomal dominant disorder with incomplete penetrance; 2) $\mathrm{PHOX} 2 \mathrm{~B}$ is the first gene for which germline mutations have been demonstrated to predispose to neuroblastoma; and 3) Hirschsprung disease was associated with an intronic single-nucleotide polymorphism of the $\mathrm{PHOX} 2 \mathrm{~B}$ gene in a case-control study. For clarifying the variable clinical expression of the autonomic nervous system dysfunction observed in neural
\end{abstract}

\section{ABSTRACT}

crest disorders, international databases of clinical symptoms and molecular test results should be established. Furthermore, the development of genetic mouse models should help to improve our understanding of the molecular mechanisms underlying neural crest disorders. (Pediatr Res 58: 1-6, 2005)

Abbreviations
ANS, autonomic nervous system
CCHS, congenital central hypoventilation syndrome
HASH-1, human achaete-scute homologous 1 gene
HSCR, Hirschsprung disease
LO-CHS, late-onset central hypoventilation syndrome
MASH-1, mammalian achaete-scute homologous 1 gene
PHOX2B, paired-like homeobox 2 b gene
RET, rearranged after transfection gene
SIDS, sudden infant death syndrome

The neural crest is a multipotent embryonic structure that gives rise to neuronal, endocrine, craniofacial, pigmentary, and conotruncal cardiac tissues (1). Neural crest disorders encompass tumors such as neuroblastomas, birth defects, and variable combinations of single or multifocal abnormalities that affect the above-listed tissues. Hirschsprung disease (HSCR) is a neural crest disorder characterized by the absence of enteric ganglia along a variable length of the intestine (2). Neuroblastoma is a neural crest-derived tumor (3) and accounts for $\sim 10 \%$ of all cancers in children. Congenital central hypoventilation syndrome (CCHS), or "Ondine's curse," has been classified among the neural crest disorders because it occurs in association with HSCR and neural crest-derived tumors $(4,5)$. Evidence that the paired-like homeobox transcription factor

Received December 22, 2004; accepted March 21, 2005.

Correspondence: Claude Gaultier, Service de Physiologie, Hôpital Robert Debré, 48 Bd Serurier, 75019 Paris, France; e-mail: claude.gaultier@rdb.ap-hop-paris.fr.

DOI: 10.1203/01.PDR.0000166755.29277.C4
Phox $2 b$ is pivotal to the development of the visceral nervous system in mice, including neural crest derivatives that control autonomic ganglia, points to $\mathrm{PHOX} 2 \mathrm{~B}$ as a candidate gene for CCHS, HSCR, and neuroblastoma $(6,7)$. Recent studies have shown that 1) $\mathrm{PHOX} 2 \mathrm{~B}$ is the major disease-causing gene for CCHS (8-12); 2) $\mathrm{PHOX} 2 \mathrm{~B}$ is the first gene for which germline mutations have been found in patients with neuroblastoma $(13,14)$; and 3) two novel intronic single-nucleotide polymorphisms (SNPs) and one deletion mutation in the $P H O X 2 B$ gene have been identified in patients with HSCR, suggesting that $P H O X 2 B$ haploinsufficiency may predispose to $\operatorname{HSCR}(15,16)$. Furthermore, studies in transgenic mice have produced data on the homozygous and heterozygous $P H O X 2 B$ knockout phenotypes (17).

\section{PHOX2B Is Essential for the Development of Neural Crest Derivatives in Mice}

Neural stem cells in the developing nervous system can give rise to a wide variety of distinct neuronal subtypes. Consider- 
able progress has been made in identifying the molecular signals that control neuronal specification and differentiation. For example, the generation of autonomic neurons from neural crest cells is induced by an extrinsic signal (bone morphogenic proteins) that elicits the expression of a network of transcription factors, which, in turn, control autonomic neuron differentiation (18). This network includes Mash-1 (Ascl1-Mouse Genome Information), the mammalian homologue of the Drosophila archaete scute gene complex, and the paired homeodomain transcription factor Phox $2 b$. Phox $2 b$ and its paralogue, Phox $2 a$, bind to the promoter of the subtype-specific noradrenergic marker genes tyrosine hydroxylase and dopamine- $\beta$ hydroxylase, activating their transcription. Mash-1 and Phox $2 b$ can induce the differentiation of noradrenergic neurons from neural crest precursor cells (19-22) and are essential determinants of the noradrenergic phenotype, both central and peripheral $(6,7,23,24)$. Depending on the subtype of noradrenergic neuron, they can act in different epistatic orders and interact with distinct transcription factors in various noradrenergic cell types $(18,25)$. Furthermore, Mash-1 and Phox $2 b$ work in concert during the generation of parasympathetic cholinergic (26) and serotonergic neurons $(27,28)$.

Homozygous Phox $2 B$-deficient mice die shortly after midgestation (6). The cause of death is complete absence of noradrenergic neurons, including those of the locus coeruleus in the CNS (6). Homozygous Phox $2 b$-deficient embryos lack sympathetic, parasympathetic, and enteric ganglia (6). Furthermore, Phox $2 b$ controls the development of peripheral chemoreceptors and afferent visceral pathways (17). In homozygous Phox $2 b$ deficient mice, the neural crest-derived carotid body degenerates, as do the three epibranchial placode-derived visceral sensory ganglia (geniculate, petrosal, and nodose), whereas the nucleus of the solitary tract, which integrates all visceral information, never forms (17).

Heterozygous Phox $2 b$ newborn mice develop normally after birth. Nevertheless, they have abnormal function of chemical respiratory control and dysgenesis of the petrosal chemoreceptors, which may underlie the neonatal respiratory phenotype (17) characterized by an abnormal duration of sleep apneas during the first days of life (J.G., personal observations). Therefore, the respiratory phenotype of heterozygous Phox $2 b$ partly models the respiratory phenotype of CCHS patients.

\section{PHOX2B, the Major Disease-Causing Gene for CCHS}

Clinical features of CCHS. CCHS is a very rare disorder with an estimated prevalence of 1 in 200,000 live births (29). Sleep-dependent hypoventilation, especially during non-rapid eye movement sleep, is the hallmark of CCHS $(4,5)$. Clinical onset occurs in the first few postnatal days in most patients, in the absence of neuromuscular disorders, heart or lung disease, or identifiable brain lesions. There is considerable within- and between-patient variability in the severity of hypoventilation. Hypoventilation is present during wakefulness in the most severe cases. A functional characteristic of CCHS patients is absence or marked blunting of the ventilatory response to sustained hypercapnia. CCHS patients also have a depressed ventilatory response to sustained hypoxia. Peripheral chemo- receptors are functional in the milder cases (4). In addition to respiratory abnormalities, CCHS patients have functional disorders of autonomic nervous system (ANS) control with abnormalities in heart rate, blood pressure, and pupil diameter control $(4,5,30,31)$. Furthermore, the enteric nervous system may be abnormal, with $\sim 15-20 \%$ of patients having Hirschsprung disease (HSCR) $(4,5,29)$. It is interesting that most of the CCHS patients with HSCR have aganglionosis extending proximal to the sigmoid (29). Neural crest-derived tumors such as neuroblastoma, ganglioneuroblastoma, and ganglioneuroma are present in $\sim 5 \%$ of patients with CCHS (3). Finally, a few patients exhibit central hypoventilation syndrome during infancy or early childhood (4). Although late-onset central hypoventilation syndrome (LO-CHS) is very probably a heterogeneous condition, relationships between a subgroup of LO-CHS and CCHS have been debated.

Genetic basis for CCHS. A genetic basis for CCHS is supported by several lines of evidence: 1) although CCHS is usually a sporadic disorder, familial cases have been reported in monozygotic twins, female siblings, and male-female halfsiblings $(4,5) ; 2)$ concomitant presence of genetically determined conditions, i.e. HSCR and neuroblastoma, has been described (3-5); and 3) more important, vertical transmission of CCHS has been reported $(32,33)$. In addition, a child with CCHS was born to a mother who had a neural crest tumor, suggesting differences in the clinical expression of neural crest disorders (34). Furthermore, investigations in parents of CCHS patients have found a high prevalence of dysautonomic symptoms $(35,36)$.

The candidate-gene approach has been used to identify gene mutations in CCHS. PHOX2B is a candidate gene for CCHS. The PHOX2B gene in humans is located on chromosome $4 \mathrm{p} 12$ and encodes a highly conserved homeobox domain transcription factor (314 amino acids), with two short and stable polyalanine repeats of nine and 20 residues, respectively (37). Recent studies have shown $P H O X 2 B$ mutations in the majority of CCHS patients (Table 1) (8-12). Most of the mutations consisted in alanine expansions within the polyalanine stretch of $P H O X 2 B$ exon 3 (Table 1). Importantly, in individuals who are heterozygous for length variants of the polyalanine stretch of $P H O X 2 B$ exon 3, the largest allele is prone to unsuccessful amplification by DNA polymerase, indicating a need for improving methodologic approaches (11). PHOX2B polyalanine expansion mutations have also been identified in some patients with LO-CHS (Table 1) $(11,12,38)$, suggesting a genetic link between CCHS and LO-CHS. Of particular interest is a recent case report of an adult who received a diagnosis of LO-CCHS at $35 \mathrm{y}$ of age and carried an alanine $P H O X 2 B$ mutation and had two daughters with LO-CHS and the same PHOX2B mutation as their father (39). The function of polyalanine stretches is largely unknown in humans (40). Nevertheless, there is growing evidence for a common disease-causing mechanism resulting from heterozygous polyalanine expansions and consisting of a protein misfolding leading to cytoplasmic aggregation of both mutant and wild-type proteins and therefore loss of nuclear transactivation function (40). Further evidence that $P H O X 2 B$ is the primary CCHS gene comes from a few case reports of children who have CCHS and have no polyala- 
Table 1. Molecular analysis of PHOX2B mutations in patients with CCHS and with LO-CHS

\begin{tabular}{|c|c|c|c|}
\hline & \multicolumn{2}{|c|}{ PHOX2B Mutation } & \multirow[b]{2}{*}{$\begin{array}{l}\text { Investigators } \\
\text { (Reference) }\end{array}$} \\
\hline & $\begin{array}{l}\text { Poly-Ala } \\
\text { Expansion }\end{array}$ & $\begin{array}{c}\text { Other } \\
\text { Mutations }\end{array}$ & \\
\hline 29 CCHS & 16 & 2 frameshift & Amiel et al. (8) \\
\hline $10 \mathrm{CCHS}$ & 4 & 1 frameshift & Sasaki et al. (9) \\
\hline $67 \mathrm{CCHS}$ & 65 & 1 nonsense & Weese-Mayer et al. (10) \\
\hline 188 (179 CCHS and 9 LO-CHS)* & & 3 missense & Trochet et al. (12) \\
\hline \multicolumn{4}{|c|}{ Inherited $P H O X 2 B$ Mutation } \\
\hline \multicolumn{4}{|c|}{$\begin{array}{l}\text { CCHS probands with affected offspring } \\
\text { (no. of familial cases) }\end{array}$} \\
\hline 3 & \multicolumn{2}{|c|}{ Poly-Ala expansion } & Weese-Mayer et al. (10) \\
\hline 2 & \multicolumn{2}{|c|}{ Poly-Ala expansion } & Matera et al. (11) \\
\hline \multicolumn{4}{|l|}{$\begin{array}{l}\text { Unaffected parents of CCHS patients } \\
\text { (no. of parents } \dagger \text { ) }\end{array}$} \\
\hline 8 & \multicolumn{2}{|c|}{ None } & Amiel et al. (8) \\
\hline 67 & \multicolumn{2}{|c|}{4 somatic mosaicism } & Weese-Mayer et al. (10) \\
\hline 27 & \multicolumn{2}{|c|}{1 poly-Ala expansion } & Matera et al. (11) \\
\hline & \multicolumn{2}{|c|}{1 frameshift } & Matera et al. (11) \\
\hline $124 \ddagger$ & \multicolumn{2}{|c|}{10 somatic mosaicism } & Trochet et al. (12) \\
\hline
\end{tabular}

Poly-Ala, polyalanine.

* Including the 29 CCHS patients from Amiel et al. (8).

$\dagger$ Unaffected parents for whom blood samples were available.

$\ddagger$ Including 105 pairs of parents and 19 single parents.

nine repeat expansion but exhibit other $P H O X 2 B$ mutations, such as frameshift mutation $(8,11,12)$, nonsense mutation $(10)$, or missense mutation $(8,12)$ (Table 1). Finally, direct sequencing of the $P H O X 2 B$ coding sequence, the intron-exon boundaries, and the $530 \mathrm{bp}$ of the promoter region failed to detect a nucleotide variation in a small percentage of CCHS cases (12). However, two unaffected mothers of CCHS patients carried a frameshift $P H O X 2 B$ mutation and an alanine $P H O X 2 B$ mutation, respectively (11) (Table 1).

Inheritance of CCHS. The mode of inheritance is autosomal dominant. Indeed, most of the mutations found so far in affected probands with unaffected parents occurred de novo $(8,10-12)$. When the alanine expansion is transmitted from an affected parent to his or her affected child, the expansion remains stable. However, the mutation identified in the proband can be detected in DNA extracted from peripheral leucocytes of an asymptomatic parent $(10,12)$. A somatic mosaicism was detected in $4.5 \%$ of parents (Table 1) $(10,12)$. This has important implications for genetic counseling. The recurrence risk cannot be predicted accurately, as the percentage of germline mosaicism is unknown. Nevertheless, the risk may be as high as $50 \%$; consequently, prenatal diagnostic investigations should be offered in the event of a subsequent pregnancy $(10,12)$.

Genotype/phenotype correlations. Genotype/phenotype correlations have been described in CCHS patients. Weese-Mayer et al. (10) reported an association between the number of PHOX2B repeats and the number of ANS dysfunction symptoms. Furthermore, a larger number of repeats may be associ- ated with long sinus pauses in patients with CCHS (author observations). Matera et al. (11) reported a genotype/ phenotype correlation between the number of $P H O X 2 B$ repeats and the severity of the respiratory disorders. Trochet et al. (12) reported that the distribution of alanine expansion patterns differed among patient subgroups in a series of 188 CCHS cases (Fig. 1). The smallest alanine expansion was the only pattern identified in LO-CHS but was not found in any of the patients with CCHS and HSCR. However, although patients with CCHS and HSCR tend to have longer alanine expansions than do patients with isolated CCHS, the phenotype cannot be predicted accurately from the genotype, because the +7 alanine expansion is the most common pattern in both the isolated CCHS and the CCHS-plus-HSCR populations. Finally and very important, studies of genotype/phenotype interactions strongly support the possibility that CCHS patients who develop malignant neural crest-derived tumors harbor either a missense or a frameshift heterozygous mutation in the PHOX $2 B$ gene $(9,10,12)$. Thus, the results of $P H O X 2 B$ molecular testing identify a subset of CCHS patients who are at very high risk for developing malignant tumors (12).

It is interesting that a subset of CCHS patients with the $P H O X 2 B$ gene mutation are characterized by mutations in other rearranged after transfection gene (RET) pathway genes, including RET, GDNF, and the human ortholog of Mash-1 (HASH-1) $(8,41)$. Therefore, mutations in other genes may contribute to the considerable variability in CCHS phenotypes.

Finally, recent advances in functional imaging have allowed investigations of functional brain deficits during respiratory 


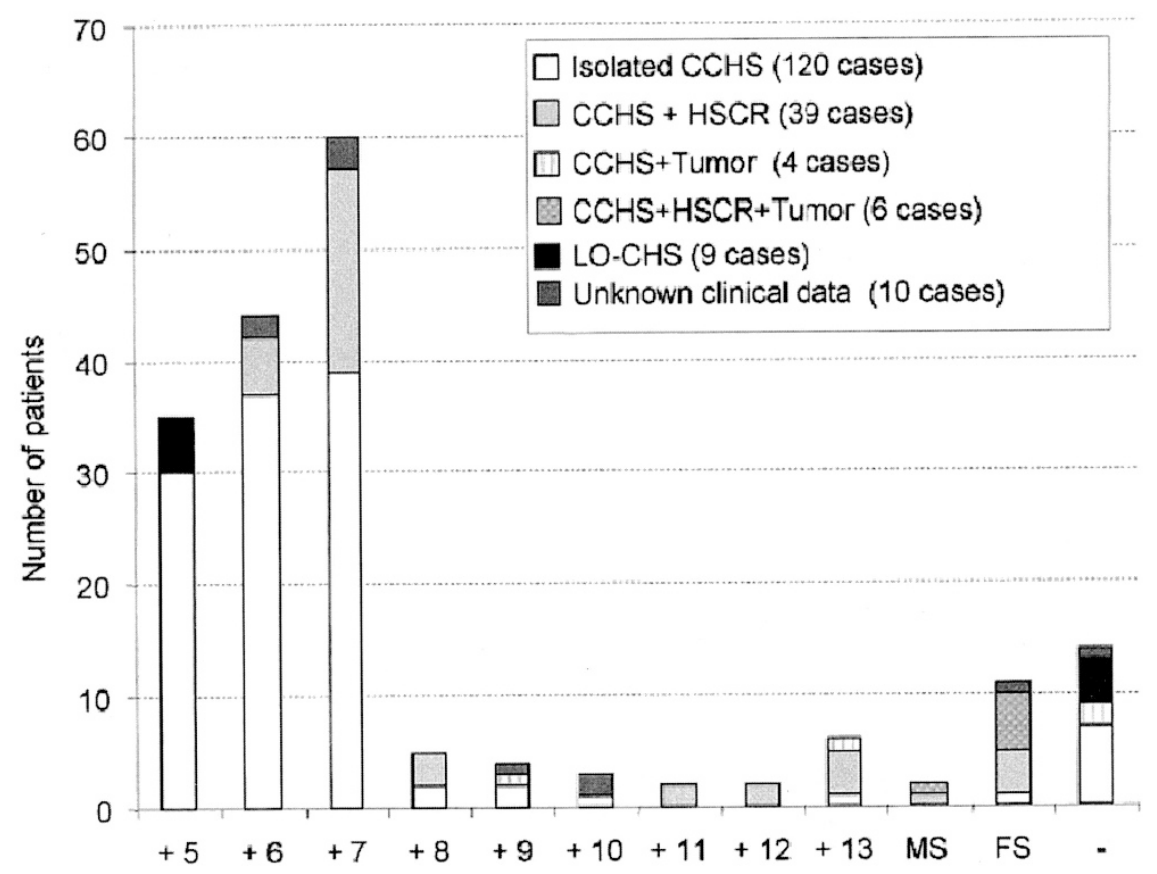

Figure 1. $P H O X 2 B$ mutations among subgroups of patients with CCHS or LO-CHS. The mutation types are reported on the $x$ axis. Alanine expansions are symbolized by a plus sign (+) followed by the number of extra alanines. MS, missense mutations; FS, frameshift mutations. The minus sign (-) represents the group of patients $(n=14)$ with no identified PHOX2B mutation. Clinical subgroups are listed in the graph key. Reprinted with permission from Trochet $e t$ al., Am J Hum Genet, 76:421-426, (92005 by The American Society of Human Genetic.

and cardiovascular challenges in CCHS patients $(42,43)$. Functional deficits have been found in brainstem areas targeted by PHOX2B expression. However, functional deficits were also observed in other areas that are not known to be targeted by $P H O X 2 B$, such as limbic structures and deep cerebellar nuclei. It is unclear whether these functional deficits are secondary to hypoxic or perfusion sequelae of abnormal developmental PHOX2B expression or reflect other unknown genetic deficits in CCHS patients.

\section{PHOX2B Haploinsufficiency May Predispose to HSCR}

HSCR is the main genetic cause of functional intestinal obstruction, with an incidence of 1/5000 live births. Patients can be classified as having short-segment HSCR $(80 \%$ of cases), in which the aganglionic segment does not extend beyond the upper sigmoid, or long-segment HSCR, with extension proximal to the sigmoid; long-segment disease is the more common pattern in CCHS patients (29). HSCR is characterized by incomplete penetrance, a marked gender-related difference in clinical expression, and variation in penetrance affecting the extent of aganglionosis. As mentioned above, HSCR can occur in combination with CCHS and also with neuroblastoma (44). It is interesting that some patients with HSCR have impaired cardiovascular and pupillary control (45) and abnormal breathing during sleep (H.T., unpublished data), suggesting that dysfunction of the autonomic component of cardiovascular, pupillary, and breathing control can be present in patients with HSCR. So far, there have been no reports of CCHS with HSCR in one of the parents.

HSCR is a complex genetic disorder that requires the interaction of multiple genes for disease expression (46-48). Mu- tations of eight susceptibility genes that belong to the RET and endothelin pathways have been identified (2). Studies in twolocus mouse models of HSCR have shown that interactions between Ret and EDNRB (endothelin receptor B) genes are central to this complex disorder (47). However, even with extensive mutation screening, a RET mutation is identified in only $50 \%$ of familial and $15-20 \%$ of sporadic HSCR cases and an $E D N R B$ mutation in approximately $5 \%$ of cases (2). Recently, the contribution of $P H O X 2 B$ to the HSCR phenotype was investigated in patients with HSCR. Garcia-Barcelo et al. (15) showed an association between HSCR and an intronic SNP in a case-control study. However, Benailly et al. (16) reported a deletion mutation in the $P H O X 2 B$ gene in a girl with syndromic short-segment HSCR. These new findings suggest that $P H O X 2 B$ haploinsufficiency may predispose to HSCR.

\section{PHOX2B, the First Gene for Which Germline Mutations Have Been Shown to Predispose to Neuroblastoma}

Neuroblastoma is a tumor of the sympathetic nervous system. Although no predisposing genes have been identified so far, several lines of evidence support the involvement of genetic factors: a few familial cases with vertical transmission and multifocality have been reported $(49,50)$, and neuroblastoma occasionally arises in patients with genetically determined congenital neural crest disorders such as HSCR and CCHS (3). The recent identification of $P H O X 2 B$ as the major disease-causing gene in CCHS pointed to $P H O X 2 B$ as a candidate gene for both familial and syndromic neuroblastoma (13). Trochet et al. (13) reported missense PHOX2B mutations in both a familial case of neuroblastoma and a patient with neuroblastoma and HSCR. In a study of families with neuro- 
blastoma, Mosse et al. (14) identified a frameshift PHOX2B mutation in one family but found no evidence for mutations in this gene in eight other families. These data suggest that PHOX2B mutations may be involved in neuroblastoma tumorigenesis but that germline mutational events in this gene may not be present in all hereditary neuroblastoma cases. Studies in larger numbers of patients will help to determine the frequency of $P H O X 2 B$ mutations in genetic and sporadic forms of neuroblastoma. Further work is needed to clarify whether 1 ) PHOX2B mutations in patients with neuroblastoma result in gain or loss of function and 2) $P H O X 2 B$ is a partner of alternative genetic events that predispose to tumorigenesis. Finally, it should be borne in mind that a child with CCHS was born to a mother with neuroblastoma, suggesting variable clinical expression of a single genetic disorder (34).

\section{Is PHOX2B a Candidate Gene for Sudden Infant Death Syndrome?}

Abnormalities in ANS control have been shown to contribute to the vulnerability of some infants to sudden infant death syndrome (SIDS) (51). Kinney et al. (52) suggested that SIDS may be related to a developmental abnormality in the medullary serotonergic network. However, the prevalence of SIDS is high in CCHS families, suggesting that these two disorders may share developmental abnormalities in ANS control (53). The recent demonstration that Mash- 1 and Phox $2 b$ transcription factors are involved in the development of central serotonergic neurons in mice $(27,28)$, the recent identification of $P H O X 2 B$ as the major disease-causing gene of CCHS, and the presence of $H A S H-1$ mutations in addition to $P H O X 2 B$ mutations in three patients with CCHS $(8,41)$ point to $P H O X 2 B$ and $H A S H-1$ as candidate genes for SIDS. However, no HASH- 1 or PHOX2B polyalanine expansion mutations were found in a group of 92 SIDS victims (54). Similarly, Kijima et al. (55) found no $P H O X 2 B$ gene mutations in 23 SIDS victims. Further genetic studies are needed in SIDS to clarify the interactions between SIDS and abnormal ANS development.

In summary. Candidate gene approaches have brought new insights into the molecular mechanisms of neural crest disorders such as CCHS, HSCR, and neuroblastoma. The finding that $P H O X 2 B$ is the major disease-causing gene for CCHS allows genetic counseling and prenatal diagnosis. Information on the potential transmission of CCHS must be disseminated to CCHS families, obstetricians, and pediatricians. Moreover, meticulous attention should be paid to infants whose mother or father has CCHS or neuroblastoma. $P H O X 2 B$ is the first gene for which germline mutations have been shown to predispose to neuroblastoma. Nevertheless, the molecular events that lead to neuroblastoma need further investigation. Furthermore, the presence of frameshift or nonsense $P H O X 2 B$ mutations in CCHS patients who developed malignant neural crest-derived tumor warrants careful follow-up of patients who carry such mutations. Among the complex genetic interactions reported so far in HSCR, $P H O X 2 B$ haploinsufficiency may play a role in the variable clinical expression of HSCR. Finally, further genetic investigations in SIDS victims and their families should further explore the $P H O X 2 B$ signaling pathway. Inter- national databases of clinical symptoms and molecular analyses should be organized to clarify the variable clinical expression of the ANS dysfunction observed in neural crest disorders. Furthermore, development of genetic mouse models is useful for improving our understanding of the molecular mechanisms underlying neural crest disorders.

Acknowledgments. We are grateful to Jean-François Brunet (CNRS UMR 8542, Ecole Normale Supérieure, Paris, France) and to Jeanne Amiel (INSERM U393 and Département de Génétique Médicale, Hôpital Necker-Enfants Malades, Paris, France) for critical reading of the manuscript.

\section{REFERENCES}

1. Le Douarin N, Kalcheim C 1999 The Neural Crest. Cambridge University Press, Cambridge

2. Amiel J, Lyonnet S 2001 Hirschsprung disease, associated syndromes, and genetics: a review. J Med Genet 38:729-739

3. Rohrer T, Trachsel D, Engelcke G, Hammer J 2002 Congenital central hypoventilation syndrome associated with Hirschsprung's disease and neuroblastoma: case of multiple neurocristopathies. Pediatr Pulmonol 33:71-76

4. Gozal D 1998 Congenital central hypoventilation syndrome: an update. Pediatr Pulmonol 26:273-282

5. Weese-Mayer DE, Shannon DC, Keens TG, Silvestri JM 1999 Idiopathic congenital central hypoventilation syndrome: diagnosis and management. American Thoracic Society. Am J Respir Crit Care Med 160:368-373

6. Pattyn A, Morin X, Cremer H, Goridis C, Brunet JF 1999 The homeobox gene Phox $2 \mathrm{~b}$ is essential for the development of autonomic neural crest derivatives. Nature 399:366-370

7. Pattyn A, Goridis C, Brunet JF 2000 Specification of the central noradrenergic phenotype by the homeobox gene Phox2b. Mol Cell Neurosci 15:235-243

8. Amiel J, Laudier B, Attie-Bitach T, Trang H, de Pontual L, Gener B, Trochet D, Etchevers H, Ray P, Simonneau M, Vekemans M, Munnich A, Gaultier C, Lyonnet S 2003 Polyalanine expansion and frameshift mutations of the paired-like homeobox gene $P H O X 2 B$ in congenital central hypoventilation syndrome. Nat Genet 33:459461

9. Sasaki A, Kanai M, Kijima K, Akaba K, Hashimoto M, Hasegawa H, Otaki S, Koizumi T, Kusuda S, Ogawa Y, Tuchiya K, Yamamoto W, Nakamura T, Hayasaka K 2003 Molecular analysis of congenital central hypoventilation syndrome. Hum Genet 114:22-26

10. Weese-Mayer DE, Berry-Kravis EM, Zhou L, Maher BS, Silvestri JM, Curran ME, Marazita ML 2003 Idiopathic congenital central hypoventilation syndrome: analysis of genes pertinent to early autonomic nervous system embryologic development and identification of mutations PHOX2b. Am J Med Genet 123:267-278

11. Matera I, Bachetti T, Puppo F, Di Duca M, Morandi F, Casiraghi GM, Cilio MR, Hennekam R, Hofstra R, Schober JG, Ravazzolo R, Ottonello G, Ceccherini I 2004 PHOX2B mutations and polyalanine expansions correlate with the severity of the respiratory phenotype and associated symptoms in both congenital and late-onset central hypoventilation syndrome. J Med Genet 41:373-380

12. Trochet D, O'Brien LM, Gozal D, Trang H, Norkenskjold A, Laudier B, Svensson PJ, Uhrig S, Cole T, Munnich A, Gaultier C, Lyonnet C, Amiel J 2005 PHOX2B genotype allows for prediction of tumour risk in congenital central hypoventilation syndrome. Am J Hum Genet 76:421-426

13. Trochet D, Bourdeau F, Janoueix-Lerosey I, Deville A, de Pontual L, Schleiermacher G, Coze C, Philip N, Frebourg T, Munnich A, Lyonnet S, Delattre O, Amiel J 2004 Germline mutations of the paired-like homeobox 2B (PHOX2B) gene in neuroblastoma. Am J Hum Genet 74:761-764

14. Mosse YP, Laudenslager M, Khazi D, Carlisle AJ, Winter CL, Rappaport E, Maris JM 2004 Germline PHOX2B mutation in hereditary neuroblastoma. Am J Hum Genet 75:727-730

15. Garcia-Barcelo M, Sham MH, Lui VC, Chen BL, Ott J, Tam PK 2003 Association study of $P H O X 2 B$ as a candidate gene for Hirschsprung's disease. Gut 52:563-567

16. Benailly HK, Lapierre JM, Laudier B, Amiel J, Attie T, De Blois MC, Vekemans M, Romana SP 2003 PMX2B, a new candidate gene for Hirschsprung's disease. Clin Genet 64:204-209

17. Dauger S, Pattyn A, Lofaso F, Gaultier C, Goridis C, Gallego J, Brunet JF 2003 Phox $2 \mathrm{~b}$ controls the development of peripheral chemoreceptors and afferent visceral pathways. Development 130:6635-6642

18. Goridis C, Rohrer H 2002 Specification of catecholaminergic and serotonergic neurons. Nat Rev Neurosci 3:531-541

19. Stanke M, Junghans D, Geissen M, Goridis C, Ernsberger U, Rohrer H 1999 The Phox $2 b$ homeodomain proteins are sufficient to promote the development of sympathetic neurons. Development 126:4087-4094

20. Stanke M, Stubbusch J, Rohrer H 2004 Interactions of Mash1 and Phox2b in sympathic neuron development. Mol Cell Neurosci 25:374-382

21. Lo L, Morin X, Brunet JF, Anderson DJ 1999 Specification of neurotransmitter identify by Phox $2 b$ proteins in neural crest stem cells. Neuron 22:693-705 
22. Lo L, Tiveron MC, Anderson DJ 1998 MASH1 activated expression of the paired homeodomain transcription factor Phox $2 \mathrm{a}$, and couples pan-neural and subtypespecific components of autonomic neuronal activity. Development 125:609-620

23. Guillemot F, Lo LC, Johnson JE, Auerbach A, Anderson DJ, Joyner AL 1993 Mammalian achaete-scute homolog 1 is required for the early development of olfactory and autonomic neurons. Cell 75:463-476

24. Hirsch MR, Tiveron MC, Guillemot F, Brunet JF, Goridis C 1998 Control of noradrenergic differentiation and Phox2a expression by Mash1 in central and peripheral nervous system. Development 125:599-608

25. Tsarovina K, Pattyn A, Stubbusch J, Muller F, van der Wees J, Schneider C, Brunet JF, Rohrer H 2004 Essential role of Gata transcription factors in sympathetic neuron development. Development 131:4775-4786

26. Muller F, Rohrer H 2002 Molecular control of ciliary neuron development: BMPs and downstream transcriptional control in the parasympathetic lineage. Developmen 129:5707-5717

27. Pattyn A, Vallsted A, Dias JM, Samad OA, Krumlauf R, Rijli FM, Brunet JF, Ericson J 2003 Coordinated temporal and spatial control of motor neuron and serotonergic neuron generation from a common pool. Genes Dev 17:729-737

28. Pattyn A, Simplicio N, van Doorninck JH, Goridis C, Guillemot F, Brunet JF 2004 Ascl1/Mash1 is required for the development of central serotonergic neurons. Nat Neurosci 7:589-595

29. Trang H, Dehan M, Beaufils F, Zaccaria I, Amiel J, Gaultier C; French CCHS Working Group 2005 The French Congenital Central Hypoventilation Syndrome Registry: general data, phenotype, genotype. Chest 127:72-79

30. Trang H, Boureghda S, Denjoy I, Alia M, Kabaker M 2003 24-hour BP in children with congenital central hypoventilation syndrome. Chest 124:1393-1399

31. Macey PM, Valderama C, Kim AH, Woo MA, Gozal D, Keens T, Harper RK, Harper RM 2004 Temporal trends of cardiac and respiratory responses to ventilatory challenges in congenital central hypoventilation syndrome. Pediatr Res 55:953-959

32. Sritippayawan S, Hamutcu R, Kun SS, Ner Z, Ponce M, Keens TG 2002 Motherdaughter transmission of congenital central hypoventilation syndrome. Am J Respir Crit Care Med 166:367-369

33. Silvestri JM, Chen ML, Weese-Mayer DE, McQuitty JM, Carveth HJ, Nielson DW, Borowitz D, Cerny F 2002 Idiopathic congenital central hypoventilation syndrome: the next generation. Am J Med Genet 112:46-50

34. Devriendt K, Fryns JP, Naulaers G, Devlieger H, Alliet P 2000 Neuroblastoma in a mother and congenital central hypoventilation in her daughter: variable expression of the same genetic disorder. Am J Med Genet 90:430-431

35. Marazita ML, Maher BS, Cooper ME, Silvestri JM, Huffman AD, Smok-Pearsall SM, Kowal MH, Weese-Mayer DE 2001 Genetic segregation analysis of autonomic nervous system dysfunction in families of probands with idiopathic congenital central hypoventilation syndrome. Am J Hum Med Genet 100:229-236

36. Weese-Mayer DE, Silvestri JM, Huffman AD, Smok-Pearsall SM, Kowal MH, Maher BS, Cooper ME, Marazita ML 2001 Case/control family study of autonomic nervous system dysfunction in idiopathic congenital central hypoventilation syndrome. Am J Med Genet 100:237-245

37. Yokoyama M, Watanabe H, Nakamura M 1999 Genomic structure and functional characterization of NBPhox (PMX2B), a homeodomain protein specific to catecholaminergic cells that is involved in second messenger-mediated transcriptional activation. Genomics 59:40-50

38. Trang H, Laudier B, Trochet D, Munnich A, Lyonnet S, Gaultier C, Amiel J 2004 PHOX2B gene mutation in a patient with late-onset hypoventilation. Pediatr Pulmonol 38:349-351

39. Weese-Mayer DE, Berry-Kravis EM, Zhou L 2005 Adult identified with congenital central hypoventilation syndrome-mutation in $\mathrm{PHOX} 2 \mathrm{~B}$ and late-onset CHS. Am J Respir Crit Care Med 171:88
40. Amiel J Trochet D, Clement-Ziza M, Munnich A, Lyonnet S 2004 Polyalanine expansions in humans. Hum Mol Genet 13:R235-R243

41. de Pontual L, Nepote V, Attie-Bitach T, Al Halabiah H, Trang H, Elghouzzi V, Levacher B, Benihoud K, Auge J, Faure C, Laudier B, Vekemans M, Munnich A, Perricaudet M, Guillemot F, Gaultier C, Lyonnet S, Simonneau M, Amiel J 2003 Noradrenergic neuronal development is impaired by mutation of the proneural HASH-1 gene in congenital central hypoventilation syndrome (Ondine's curse). Hum Mol Genet 12:3173-3180

42. Macey PM, Woo MA, Macey KE, Keens T, Saeed MM, Alger JR, Harper RM 2005 Hypoxia reveals posterior thalamic, cerebellar, midbrain and limbic deficit in congenital central hypoventilation syndrome. J Appl Physiol 98:958-969

43. Harper RM, Macey PM, Woo MA, Macey KE, Keens T, Gozal D, Alger JR 2005 Hypercapnic exposure in congenital central hypoventilation syndrome reveals CNS respiratory control mechanisms. J Neurophysiol 93:1647-1658

44. Maris JM, Chatten J, Meadows AT, Biegel JA, Brodeur GM 1997 Familial neuroblastoma: a three-generation pedigree and a further association with Hirschsprung. Med Pediatr Oncol 28:1-5

45. Staiano A, Santoro L, De Marco R, Miele E, Fiorillo F, Auricchio A, Carpentieri ML, Celli J, Auricchio S 1999 Autonomic dysfunction in children with Hirschsprung's disease. Dig Dis Sci 44:960-965

46. Bolk S, Pelet A, Hofstra RM, Angrist M, Salomon R, Croaker D, Buys CH, Lyonnet S, Chakravarti A 2000 A human model for multigenic inheritance: phenotypic expression in Hirschsprung disease requires both the RET gene and a new 9q31 locus. Proc Natl Acad Sci USA 97:268-273

47. Carrasquillo MM, McCallion AS, Puffenberger EG, Kashuk CS, Nouri N, Chakravarti A 2002 Genome-wide association study and mouse model identify interaction between RET and EDNRB pathways in Hirschsprung disease. Nat Genet 32:237-244

48. McCaillon AS, Stames E, Conlon RA, Chakravarti A 2003 Phenotype variation in two-locus mouse models of Hirschsprung disease: tissue-specific interaction between Ret and Ednrb. Proc Natl Acad Sci USA 100:1826-1831

49. Maris JM, Kyemba SM, Rebbeck TR, White PS, Sulman EP, Jensen SJ, Allen C, Biegel JA, Brodeur GM 1997 Molecular genetic analysis of familial neuroblastoma. Eur J Cancer 33:1923-1928

50. Maris JM, Weiss MJ, Mosse Y Hii G, Guo C, White PS, Hogarty MD, Mirensky T, Brodeur GM, Rebbeck TR, Urbanek M, Shusterman S 2002 Evidence for a hereditary neuroblastoma predisposition locus at chromosome 16p12-13. Cancer Res 62:66516658

51. Harper RM, Kinney HC, Fleming PJ, Thach PT 2000 Sleep influences on homeostatic functions: implications for sudden infant death syndrome. Respir Physiol 119:123132

52. Kinney HC, Filiano JJ, White WF 2001 Medullary serotoninergic network deficiency in the sudden infant death syndrome: review of 15 -year study of a single dataset. J Neuropathol Exp Neurol 60:228-247

53. Weese-Mayer DE, Silvestri JM, Marazita ML, Hoo JJ 1993 Congenital central hypoventilation syndrome: inheritance and relation to sudden infant death syndrome. Am J Med Genet 47:360-367

54. Weese-Mayer DE, Berry-Kravis EM, Zhou L, Maher BS, Curran ME, Silvestri JM, Marazita ML 2004 Sudden infant death syndrome: case-control frequency differences at genes pertinent to early autonomic nervous system embryologic development. Pediatr Res 56:391-395

55. Kijima K, Sasaki A, Niki T, Umetsu K, Osawa M, Matoba R, Hayasaka K 2004 Sudden infant death syndrome is not associated with the mutation of PHOX2B gene, a major causative gene of congenital central hypoventilation syndrome. Tohoku J Exp Med 203:65-68 